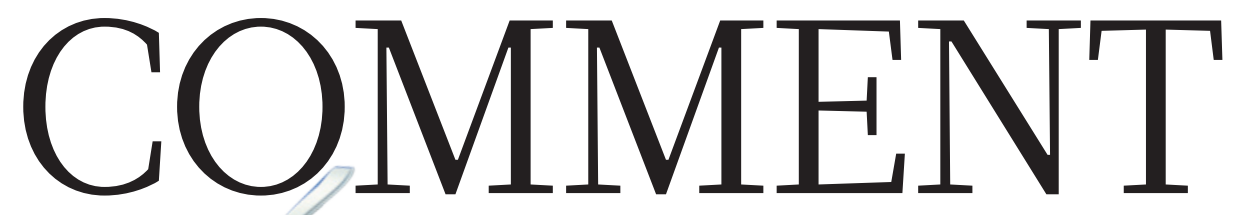

MEDICINE Deregulation lobby is using stem-cell therapies to push its cause $\mathbf{p . 3 3 6}$
BIOLOGY A hymn to symbiosis and those who work on it $\mathbf{p . 3 3 8}$
FIGURES Colour-blind correspondents find too many red-green images p.340
PoLICY Is NIH mandate on the sex of cells and animals too much or too little? p.340
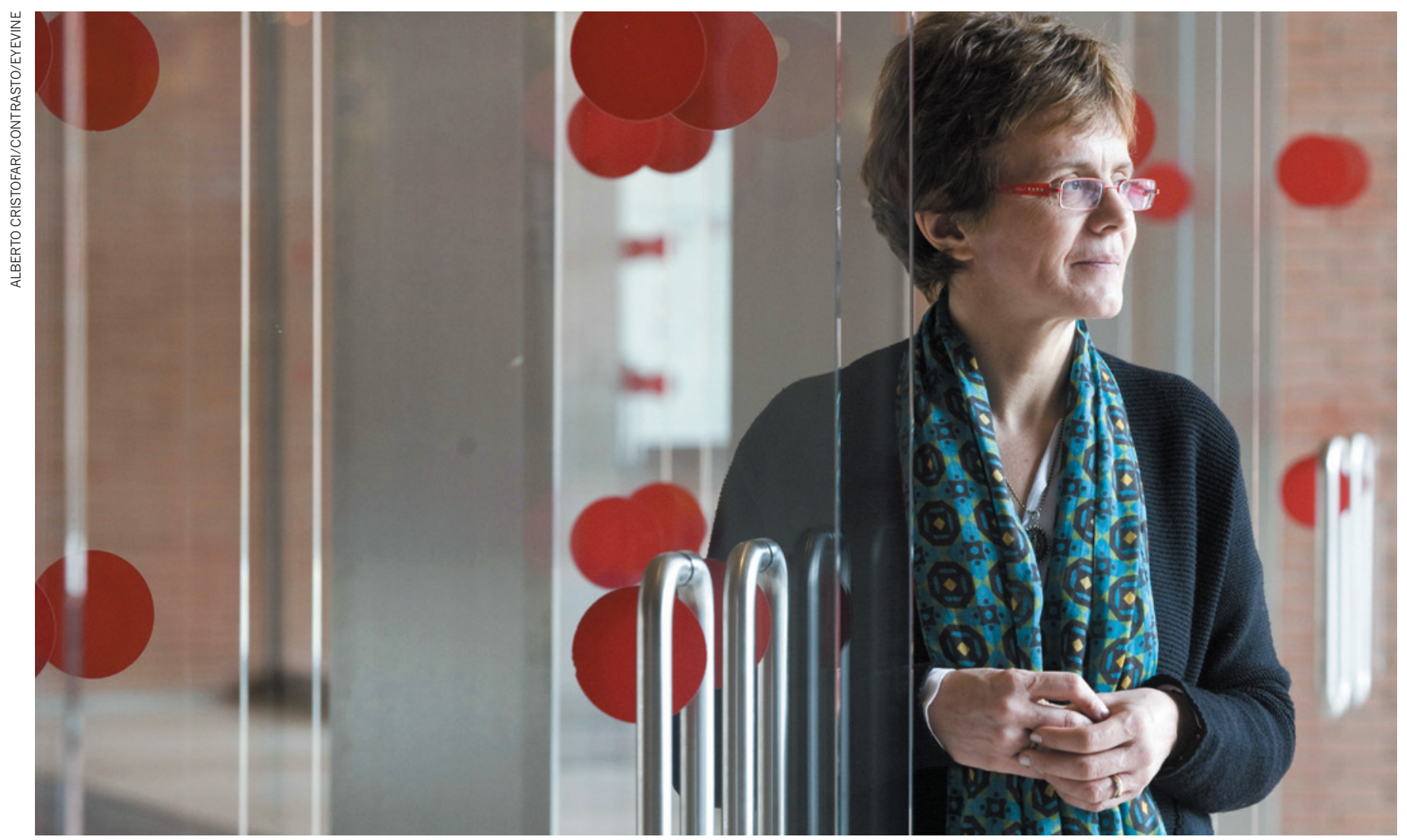

Italian stem-cell researcher Elena Cattaneo.

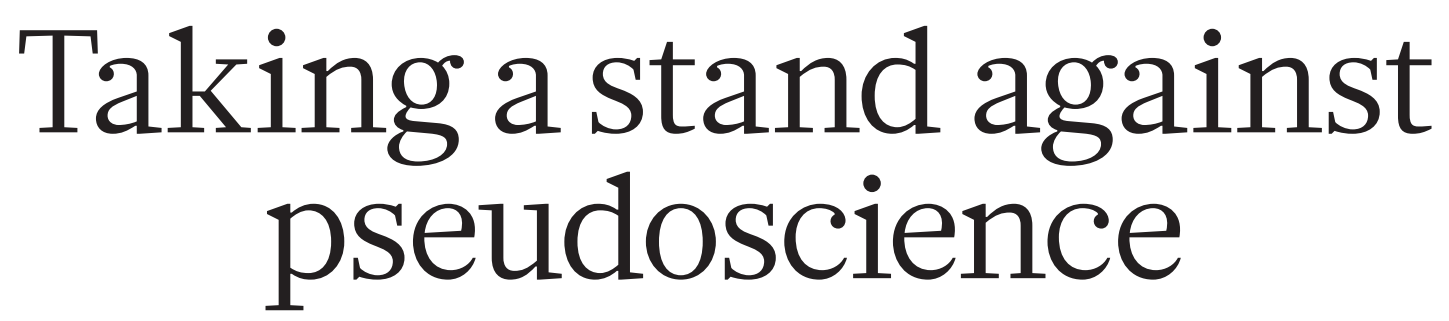

Elena Cattaneo and Gilberto Corbellini are among the academics working to protect patients from questionable stem-cell therapies. Here, they share their experiences and opinions of the long, hard fight for evidence to prevail.

S

cientists get the most satisfaction from working long hours at the bench with like-minded colleagues, but sometimes their duty lies elsewhere, even if it means missing grant deadlines and receiving threatening letters. When lax clinical standards endangered Italy's health-care system and patients, we were among those who left the comfort of our labs and offices to fight for evidence to prevail.

Since its creation in 2009, the Stamina Foundation, a private organization in Italy, has been claiming that stem cells collected from human bone marrow can be transformed into neural cells by exposure to retinoic acid, an important molecule in embryonic development. Stamina’s founder Davide Vannoni, who has not trained as a scientist or physician, holds that injections with these cells can treat conditions as diverse as Parkinson's disease, muscular dystrophy and spinal muscular atrophy. $\mathrm{He}$ has not published in the peer-reviewed literature. (PubMed searches for Vannoni $>$ 


\section{STAMINA SAGA}

The ups and downs of Italy's struggle with stem-cell-therapy claims.

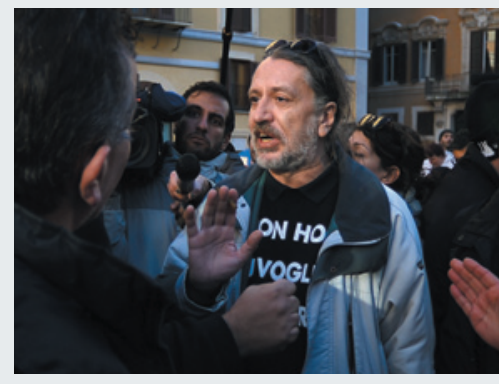

2011

The Stamina Foundation, founded by Davide Vannoni (pictured) sets up operations in a public hospital in Brescia, Italy.

\section{MAY 2012}

The Italian Medicines Agency shuts down Stamina operations because of safety concerns.

\section{MARCH 2013}

Italian health minister allows Stamina treatments to continue; 13 leading Italian stem-cell scientists write a letter in protest.

\section{MAY 2013}

Italian government agrees to sponsor clinical trial of Stamina's procedure.

\section{JULY2013}

Data in Stamina patent application found to be flawed.

\section{AUGUST 2013}

Elena Cattaneo appointed as lifetime senator in Italian Senate; Stamina investigations continue.

\section{OCTOBER 2013}

Trial plans halted after scientific committee identifies problems with Stamina's protocol.

\section{DECEMBER 2013}

Decision made to form new committee to re-investigate Stamina protocol.

\section{JANUARY 2014}

Paolo Bianco, Cattaneo and Michele De Luca win public-service award from the International Society for Stem Cell Research.

\section{APRIL 2014}

Public prosecutor accuses Stamina founder of attempted fraud, and him and others of criminal conspiracy.

\section{MAY 2014}

European court rules that 'compassionate therapy' requires scientific evidence. with the key words 'stem cell' or 'neuron' return nothing.) He has moved his laboratory around and outside Italy, stating a desire to work where regulations are less strict.

Multiple scientists and government officials have found that Stamina's cellpreparation protocols are flawed and that evidence that the treatments work is wanting. Nonetheless, Italy's national health services paid for some of these procedures, and the Italian parliament even agreed to sponsor a $€ 3$-million (US\$3.9-million) clinical trial.

For most of the past two years, we and others (especially stem-cell specialists Paolo Bianco and Michele De Luca) have spoken out against these treatments. We have had to miss grant deadlines and professional meetings to make our case. We have learned to apply our investigational abilities outside our disciplines, and have come to appreciate the skills involved in helping non-scientists to grasp the value of evidence, rigour and risk assessment.

Our most recent victory came on 28 May, with the release of a ruling from the European Court of Human Rights that patients have no right to receive therapies for which there is no scientific evidence. But we are not ready to relax. Earlier this month, Marino Andolina, the Stamina Foundation's vicepresident, was appointed acting commissioner of the public hospital in Brescia, in northern Italy, where the foundation still operates; a court gave him the go-ahead to give a child the 'Stamina treatment'.

Desperate patients will always be vulnerable to exploitation. We hope that sharing our experience - and we learned some lessons the hard way - will help other investigators to join the fight against predatory pseudoscience.

\section{INTO THE FRAY}

We first became aware of Stamina's claims in August 2012. Three months before, inspectors from the Italian Medicines Agency had shut down Stamina's operations at the hospital in Brescia, deeming its cell-preparation methods unsafe. Patient groups responded with lawsuits, demanding that the 'Stamina method' be made available for anyone with a terminal illness and for its costs to be covered by Italy's public health services.

In August 2012, one Italian court ruled that a child with spinal muscular atrophy could receive the treatment. Since then, the majority of the 500 courts that patients turned to decided in favour of the treatment and ordered its administration in the Brescia hospital.

In winter 2012, we and others began alerting patients, politicians and the press - writing articles and giving dozens of interviews every week - to the view that the method lacked both regulatory precedent and scientific rationale and did not qualify for compassionate use.

Together with De Luca and Bianco, we began scrutinizing websites and Facebook pages into the small hours. We found that although Stamina presented itself as a private charitable organization, its address was that of a commercial company, Medestea, which had been fined for misleading advertising for dietary supplements. We began to collect evidence that Vannoni was trying to lobby government officials and members of parliament to have his operations exempted from regulatory oversight and to have national health plans cover untested protocols. We found that Stamina's patent applications had been rejected because the US patent office found they lacked specificity, stating in part that it was unlikely that collected cells could be induced to form desired types under the conditions described. But no one - not the journalists, public-health authorities or hospital physicians - had bothered to dig. We began talking daily with officers in the health unit of the Italian police.

By early 2013, those of us objecting to Stamina were being vilified by Vannoni and by some media outlets as keeping children from life-saving treatments. The evidence, which a small group of us had spent months collecting and distributing, was largely ignored. We knew that there can be no compassion without safety and efficacy, and that we needed to stay vocal, lucid and rational. Most of all, we had to avoid succumbing to the feeling that we had done all that we could be expected to do.

\section{ON TRIAL}

We prepared 40-page dossiers for every politician whom we could reach, and the legislature held hearings for Stamina advocates and challengers to make their cases. Vannoni was unable even to remember the names of the clinicians with whom he worked.

In May 2013, the government promised to pay for a \$3.9-million clinical trial, even though Vannoni had not presented evidence from animal or cell-based studies, or even established cell-preparation protocols that guard against contamination. Here was a dilemma: the trial would be an appalling waste of meagre public money, yet some of us thought that it would be better than unknown cells being injected into children. At least for a rigorous trial, cells would be prepared by an authorized laboratory under strict quality controls and the protocol could be scrutinized.

In August 2013, the Italian President Giorgio Napolitano appointed one of us (E.C.) and the Nobel-prizewinning physicist Carlo Rubbia as Senators for Life in the upper house of the legislature - positions that are usually reserved for politicians. 


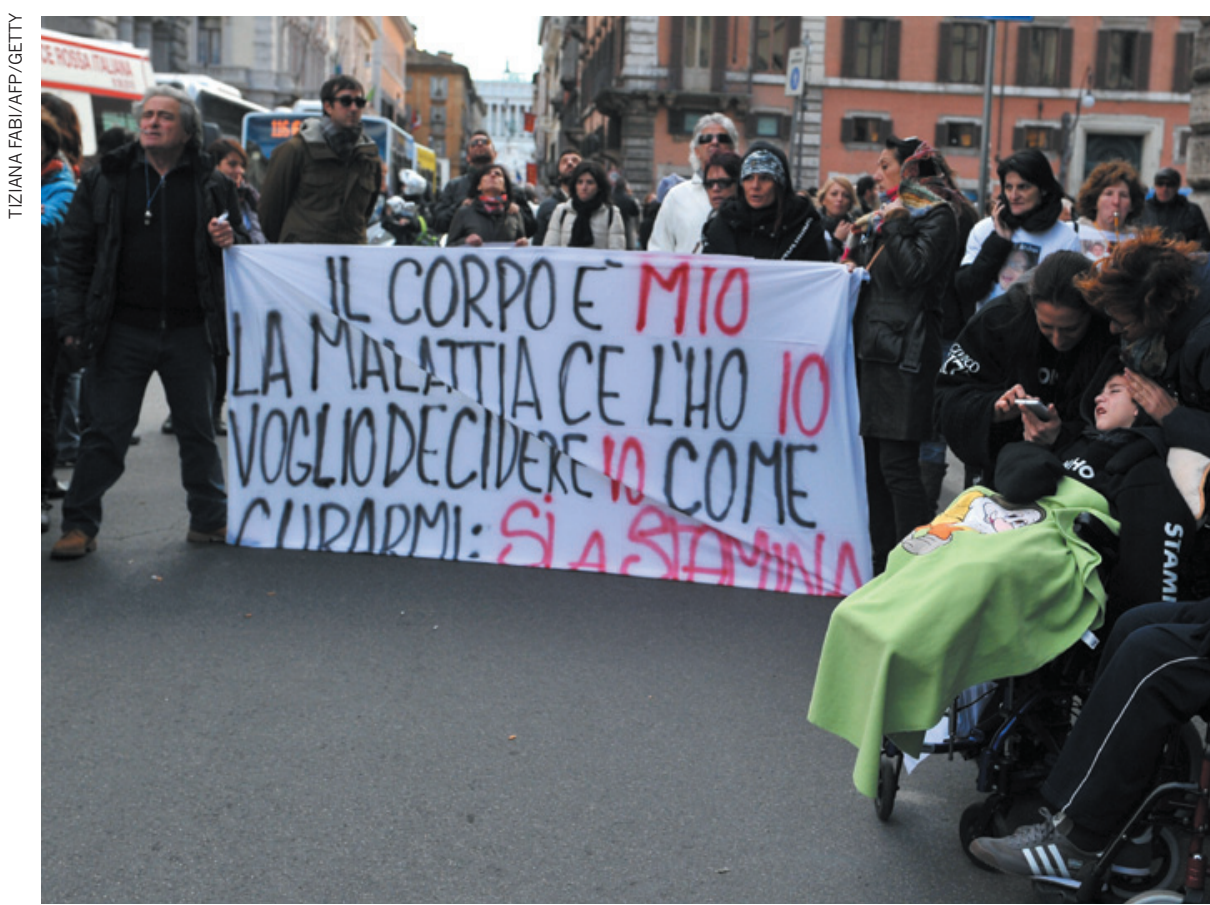

Patient advocates campaigning in November 2013 for access to the Stamina method.

The appointments, part of an effort to strengthen science in Italy, gave our band of researchers investigating Stamina greater access to politicians.

As part of the requirements for the clinical trial, Vannoni revealed his putative method for preparing cells. A scientific committee appointed by Italy's health minister found, among other shortcomings, that the method included flawed techniques to assess cells' identity and lacked basic screens for pathogens. An earlier analysis of frozen cells collected from Stamina found only blood cells, and no neurons. Plans to begin the trial were cancelled in October 2013.

In December 2013, another court ruled that any committee members who had previously spoken publicly against Stamina were biased, and called for the creation of another committee to re-examine the protocols. That same month, the health ministry said that the condition of three dozen patients treated with Stamina's protocols had not improved. (Vannoni maintains that patients' conditions did improve.)

Last month, the International Journal of Stem Cells published a single-author paper by Andolina, describing a boy with a severe neurodegenerative disease who had been injected with cells from his father (M. Andolina Int. J. Stem Cells 7, 30-32; 2014). The three-page paper contains no figures, no detailed methods and no supplementary materials, yet states that the boy's "movements [and] relationship with the parents", improved. Even more bafflingly, the author declares that he has "no conflicting financial interest". Last week, some scientists wrote to the journal about these concerns.
Meanwhile, Stamina's case continues to unravel. Italian police are looking into accusations against the foundation from patients' relatives. In April, after a four-year investigation, a public prosecutor accused Vannoni of attempting to fraudulently obtain public money, and along with some physicians and civil servants, also of criminal conspiracy. A judge will determine whether the cases will go to trial. Vannoni maintains that he is innocent of this and other charges.

\section{FIGHTING FOR RIGHT}

Our crusade has come at a high personal cost. The past 18 months have been a roller coaster of hope, disappointment, triumph and outrage. We have spent countless hours talking to each other and to politicians on the phone, in person and on video conferences. We prepared and shared at least six dossiers and dozens of slides. We have given interviews to newspapers and written commentaries almost weekly. We exchanged letters and comments with patient organizations; we established relationships with doctors at the public hospital that had housed Stamina, which has now distanced itself from Vannoni.

Every morning, we reviewed the battlefield in detail. We had to be prepared to change plans at the last minute when Stamina won a media, political or regulatory skirmish. Since June 2013, both of us, along with De Luca and Bianco, have been repeatedly asked by students' associations, university professors, science-festival organizers, patient associations and other groups to give lectures on the Stamina case. We never turn down these requests. Those of us who run research groups (E.C., De Luca and Bianco) estimate that we have each sacrificed 60-80 weeks of lab time so far and have delayed submitting papers. We often catch up with our students and lab members at night and by e-mail.

We learned to avoid appearing on television shows on which cool reason is drowned out by strong emotional messages. Over several months, some of us received threatening letters and insults from people who felt that we lacked compassion for dying patients. Several of these letters were serious enough that we forwarded them to police. Our institutions filed complaints against unknown people hanging around our labs. Our universities were the target of e-mail and other cyberattacks.

Gathering support from the international community has proved invaluable. It underlined that we were not just local troublemakers, but had worldwide backing. An advocacy award given to E.C., Bianco and De Luca by the International Society for Stem Cell Research boosted our credibility in Italy, as did statements from Nobel laureate and stem-cell pioneer Shinya Yamanaka and publications in the scientific literature.

At home, finding the right allies and getting the best from them was key. We need to be able to talk with everyone, regardless of their scientific knowledge - from taxi drivers to lawyers. Some people welcome the documentation and persistence that comes naturally to a scientist. Others want to debate values and opinions; it is important to respect and engage with this, steadily explaining the difference between beliefs and facts.

Nurturing relationships with fellow scientists involved in the battle was also key. We

"We have each
sacrificed
60 - 80 weels
of lab time
so far."
had to learn to be generous and to remember that we shared a single goal. In public advocacy, the prima donna attitude is not helpful. Maintaining valid and effective political and communicative actions requires a united front.

But it has all been worth it. Now, thanks to the European Court ruling and a Senate investigation into the case that launched three months ago, we are hopeful that these dubious treatments will soon be banished from Italy; they were displaced from Switzerland in 2011 and from Cape Verde earlier this year. We recommend that all scientists stand up for the scientific method. Science depends on public institutions and is done in the public interest - we have a duty to defend both.

Elena Cattaneo is at the Department of Biosciences and director of the Centre for Stem Cell Research at the University of Milan, Italy. Gilberto Corbellini is a historian of medicine and a bioethicist at the University of Rome La Sapienza, Italy. e-mail:elena.cattaneo@unimi.it 